\title{
ע Perusterveydenhuollon johtajien kokemuksia koronaviruspandemian vaikutuksista digitaaliseen työkulttuuriin ja sen johtamiseen
}

Koronaviruspandemian aiheuttama krïsitilanne on muokannut työkulttuuria terveydenhuollossa, jossa on turvauduttu yhä voimakkaammin digitaalisiin ratkaisuihin koronaviruksen leviämisen ehkäisemiseksi. Koronaviruspandemian vaikutuksia digitaaliseen työkulttuurïn ja sen johtamiseen on tutkittu vähän ja tietoa tarvitaan muun muassa terveydenhuollon organisaatioiden toiminnan jatkuvaan arviointiin ja kehittämiseen.

Tämän kuvailevan laadullisen tutkimuksen tarkoituksena on kuvata perusterveydenhuollon johtajien kokemuksia koronaviruspandemian vaikutuksista digitaaliseen työkulttuuriin ja sen johtamiseen. Tutkimuksen aineisto kerättiin puolistrukturoiduin yksilöhaastatteluin perusterveydenhuollon johtajilta $(n=21)$ kolmesta kunnasta ja yhdestä kuntayhtymästä eri puolilta maata touko-marraskuussa 2020. Aineisto analysoitiin induktiivisella sisällön analyysilla.

Tulosten mukaan koronaviruspandemian vaikutukset digitaaliseen työkulttuurïn liittyivät digitaalisen työkulttuurin kehittymiseen, muutokseen työnluonteessa sekä työyhteisön muutosvalmiuteen. Koronaviruspandemian vaikutukset digitaalisen työkulttuuriin johtamiseen liittyivät puolestaan muutosjohtamiseen, johtajan työn luonteen muutokseen ja johtajien muutosvalmiuteen.

Johtopäätöksenä voidaan todeta, että koronaviruspandemia muutti nopeasti ja pysyvästi perusterveydenhuollon digitaalista työkulttuuria. Erityisesti digitaalisten työvälineiden käytön lisääntyminen muutti työssä tapahtuvaa kanssakäymistä. Johdon tuki koettiin tärkeänä digitaalisen työkulttuurin muutoksessa, sillä se stressasi ja kuormitti työntekijöitä. Tulevaisuudessa johtajien tulisi kiinnittää etäjohtamisessa huomiota suhteiden ylläpitämiseen työntekijöiden kanssa. Lisäksi niin työntekijöiden kuin johtajien IT-osaamiseen olisi syytä kiinnittää huomiota. Tutkimuksen tuloksia voidaan hyödyntää digitaalisten terveyspalveluiden ja työkulttuurin kehittämisessä, johtamisessa, koulutuksessa ja työyhteisöjen muutosvalmiuden tukemisessa.

ASIASANAT: digitalisaatio, johtaminen, työkulttuuri, COVID-19

ANNIKA RAVELIN, ELINA LAUKKA, TARJA HEPONIEMI, ANU KAIHLANEN, OUTI KANSTE 


\section{YDINASIAT}

- Aiemman tutkimuksen mukaan koronaviruspandemia on lisännyt digitaalisten työkalujen käyttöä terveydenhuollossa ja niiden käyttöönotossa johtajien rooli on havaittu tärkeäksi.

- Koronaviruspandemia vaikutti digitaalisen työkulttuurin kehittymiseen, muutti työn luonnetta ja työyhteisön muutosvalmiutta.

- Jatkossa olisi hyvä tutkia digitaalisten työvälineiden kautta käytävää kanssakäymistä, digitalisaation vaikutuksia työhyvinvointiin sekä koronaviruspandemian aiheuttaman digitaalisen muutoksen pysyvyyttä.

\section{JOHDANTO}

Kiinassa todettiin joulukuussa 2019 keuhkokuumetapauksia, joiden aiheuttajaksi tunnistettiin uusi koronavirus, SARS-CoV-2 (1). Uuden koronaviruksen aiheuttama tauti tunnetaan nimellä COVID- 19 (1) ja se julistettiin maaliskuussa 2019 maailmanlaajuiseksi pandemiaksi (2). Koronaviruspandemian vakavuus on herättänyt poikkeuksellisen paineen terveydenhuoltojärjestelmiin ja terveydenhuollon työntekijöihin haastaen koko terveydenhuoltoalan vastaamaan muuttuneeseen tilanteeseen nopeasti (3). Koronaviruspandemia on vaatinut terveydenhuoltojärjestelmiä kehittämään uusia toimintamalleja (4), joissa on turvauduttu yhä enemmän digitaalisiin ratkaisuihin ihmisten välisten fyysisten kontaktien välttämiseksi ja koronaviruksen leviämisen ehkäisemiseksi. (4, 5). Digitalisaation ja tekoälyn hyödyntäminen myös hoidon tarpeen arvioinnissa tai diagnostiikassa ovat lisääntyneet koronaviruspandemian aikana (4). Digitalisaation ansiosta hoitoa on ollut mahdollista tarjota karanteeniin asetetuille etänä (6).

Koko maailmaa kohdanneen koronaviruspandemian odotetaankin vauhdittavan digitaalista muutosta julkisella sektorilla (7). Koronapandemian vaikutuksista digitaaliseen työkulttuuriin ja sen johtamiseen on saatavilla vain vähän tutkimustietoa, ja tietoa tarvitaan toiminnan jatkuvaan arviointiin ja kehittämiseen. Johtamista yllättävissä kriisitilanteissa ja digitaalisissa työympäristöissä on tutkittu myös vasta vähän (8). Johdon vastuu on ratkaiseva digitaalisessa muutoksessa $(8,9)$ ja työsuorituksen ylläpitämisessä kriisitilanteessa (8). Tämän tutkimuksen tarkoituk- sena on kuvata perusterveydenhuollon johtajien kokemuksia koronaviruspandemian vaikutuksista digitaaliseen työkulttuuriin ja sen johtamiseen. Tutkimus toteutettiin laadullisena kuvailevana tutkimuksena haastattelemalla perusterveydenhuollon johtajia. Tutkimuksen tavoitteena on tuottaa uutta tietoa terveydenhuollon digitaalisen työkulttuurin kehittämiseen, jota voidaan hyödyntää johtamistyössä, koulutuksessa ja työyhteisöjen muutosvalmiuden tukemisessa.

\section{DIGITALLINEN TYÖKULTTUURI JA SEN JOHTAMINEN TERVEYDENHUOLLOSSA}

Koronaviruspandemia ja sen lisäämä digitalisaation hyödyntäminen ovat vaikuttaneet terveydenhuollon työkulttuuriin $(10,11)$. Andrén ym. (12) mukaan työkulttuuri pitää sisällään organisaatiokulttuurin ja organisaation ilmapiirin. Organisaatiokulttuuri sisältää organisaation jäsenten jakamat normit ja arvot. Organisaatioilmapiiriin puolestaan kuuluu työntekijöiden käsitykset johtajuudesta, päätöksenteosta ja normeista. Tässä tutkimuksessa työkulttuuri ymmärrettiin siten, että se määrittää sitä, kuinka työntekijät ovat vuorovaikutuksessa toistensa kanssa ja kuinka organisaatio toimii. Käsitteenä se kattaa työhön ja organisaatioon liittyviä uskomuksia, ajatusmalleja sekä asenteita. Hyvän työkulttuurin saavuttaminen terveydenhuollossa edellyttää tehokasta johtamista ja järjestelmää sekä tiimityöskentelytaitoja työntekijöiltä (13).

Aikaisemman tutkimustiedon mukaan terveydenhuollon työntekijät tarvitsevat sekä organisatorista että kollegiaalista tukea uuden tekniikan käyttöönotossa ja käytössä. Kollegiaalinen ja organisatorinen tuki ovat keskeisiä tekijöitä terveydenhuollon työntekijöiden digitalisaatiosta saatujen positiivisten kokemusten rakentamisessa ja positiiviset kokemukset digitaalisen tekniikan käytöstä puolestaan vaikuttavat terveydenhuollon työntekijöiden asenteisiin ja motivaatioon digimuutokseen sopeutumisessa. (14.) Digitalisaation tarjoamista mahdollisuuksista on hyötyä vain silloin, jos työntekijät hyväksyvät uudet työvälineet (15). Työpaikkojen sosiaaliseen ympäristöön on tärkeää kiinnittää huomiota, koska tekniikan käytöllä on jonkin verran sosiaalista vaikutusta. Lisäksi positiivinen ilmapiiri parantaa asennetta digitalisaatioon (14).

Kansallisen sähköisen potilastietojärjestelmän käyttöönoton vaikutuksia terveydenhuollon työn- 
tekijöiden työhön on tutkittu englantilaisessa sairaalassa. Sähköisen potilastietojärjestelmän käyttö standardoi terveydenhuollon työntekijöiden käytäntöjä, kaventaa kliinisen päätöksenteon ammatillista autonomiaa, laajentaa sairaanhoitajien roolia ja jakaa kliinistä työtä ammatillisten rajojen sisällä ja niiden ulkopuolella. (16.) Aiemman tutkimuksen mukaan työkulttuurilla ja sähköisen potilastietojärjestelmän käyttöönoton onnistumisella on yhteys. Organisaatio, jossa terveydenhuoltohenkilöstöllä oli työkulttuuri, jolla oli monia positiivisia ominaisuuksia, kuten hyvä tasapaino itsenäisyyden, sitoutumisen, uskollisuuden ja hyväksynnän välillä onnistui muutoksessa. (17.) Andrén ym. (17) tutkimuksen tulosten mukaan organisaatio, jonka työkulttuurissa keskitytään tavoitteiden saavuttamiseen ja tehtävälähtöisyyteen, pystyy selviytymään paremmin muutoksesta.

Johtajilla on todettu olevan ratkaiseva vastuu digitaalisessa muutoksessa $(9,18)$. Työprosessien muuttaminen vaatii vahvaa johtajuutta ja muutos vaatii uusien työprosessien hyväksynnän, toimeenpanon ja sitoutumisen niiden käyttöön (19). Digitaalinen organisaation muutostilanne edellyttää johtamiselta suunnittelua eri toimijoiden, kuten työntekijöiden ja tietojärjestelmien asiantuntijoiden kanssa. Työntekijöiden sitouttaminen ja osallistaminen muutokseen ja sen suunnitteluun edistää muutoksessa onnistumista. Työntekijät, jotka ovat halukkaita osallistumaan aktiivisesti digitaalisten työvälineiden käyttöön vaikuttavat muihin ihmisiin ja tukevat käyttöönottoa. (20.)

Organisaation kaikilla johtamisen tasoilla on tärkeä rooli organisaation muutoksessa, mutta heillä on erilaiset vastuualueet ja toimivalta sen toteuttamisessa (21). Ylimmän johdon rooli on pääasiassa päätöksenteko (22), keskijohdon vastuulla on toteuttamis- ja johtamisstrategioiden kehittäminen (23), kun taas lähijohto on suorimmassa vuorovaikutuksessa työntekijöiden kanssa (24). Selkeä ja yksinkertainen visio on avainasemassa digitaalisessa muutoksessa ja johtajien tulisi välittää sitä työntekijöille $(18,20)$. Uuden sähköisen palvelun käyttöönotossa johto tarvitsee taitoja prosessin suunnitteluun ja toteuttamiseen, kuten mitä toteutusstrategiaa käytetään ja kuinka tunnistaa ja puuttua käyttöönoton estäviin tekijöihin (23). Sähköisen terveydenhuollon käyttöönotossa tulisi siirtyä oppimiskeskeiseen johtamiseen ja mukautuvaan johtamiseen, joka korostaa työntekijöiden osallistumista ja oppimismahdollisuuksia. Johdon tehtävä on auttaa työntekijöitä ymmärtämään jatkuvasti muuttuviin työkäytäntöihin liittyvät monimutkaisuudet. (9.) Tähän tutkimukseen on otettu mukaan johtajia kolmelta eri tasolta, koska heidän kaikkien panos on tärkeää muutoksen läpiviennissä (21).

\section{TUTKIMUKSEN TARKOITUS JA TUTKIMUSKYSYMYKSET}

Tämän tutkimuksen tarkoituksena on kuvata perusterveydenhuollon johtajien kokemuksia koronaviruspandemian vaikutuksista digitaaliseen työkulttuuriin ja sen johtamiseen. Tutkimuskysymykset ovat seuraavat:

1. Millaisia kokemuksia johtajilla on koronaviruspandemian vaikutuksesta digitaaliseen työkulttuuriin?

2. Millaisia kokemuksia johtajilla on koronaviruspandemian vaikutuksesta digitaalisen työkulttuurin johtamiseen?

\section{AINEISTO JA MENETELMÄT}

\section{AINEISTON KERUU JA HAASTATELTAVAT}

Tämän kuvailevan laadullisen tutkimuksen aineisto kerättiin puolistrukturoiduilla haastatteluilla touko- ja marraskuun 2020 välillä 21 perusterveydenhuollon johtajalta kolmesta kunnasta ja yhdestä kuntayhtymästä eri puolilta maata. Puolistrukturoitu haastattelumenetelmä soveltui tutkimukseen, sillä mielenkiinnon kohteena olivat perusterveydenhuollon johtajien kokemukset (27). Kunnat tuottivat perusterveydenhuollon palveluja yksittäin kahdessa kunnassa, yhdessä kunnassa yhteistyössä yksityisen sektorin kanssa sekä yhdessä kuntayhtymänä. Nämä kunnat ja kuntayhtymä valittiin tähän tutkimukseen, koska ne ovat edelläkävijöitä digitaalisten terveyspalvelujen tuottamisessa. Kaikilla mukaan valituilla oli esimerkiksi e-terveyspalvelut potilasportaaleina ja videoneuvotteluina. Lisäksi kaikissa terveys- ja hyvinvointikeskuksissa oli otettu käyttöön kansallisesti rahoitettu itsepalvelupotilasportaali Omaolo (25).

Puolistrukturoitu haastattelurunko kehitettiin tutkimusryhmässä ja se testattiin yhden perusterveydenhuollon johtajan kanssa ennen varsinaisten haastattelujen aloittamista. Esihaastattelun aineisto otettiin mukaan tutkimusaineistoon. Haastateltavat valittiin harkinnanvaraisesti, siten että kustakin organisaatiosta pyydettiin 
lista johtajista, ja yksi tutkija poimi sieltä valintakriteerien kannalta soveltuvat haasteltavat ja lähestyi heitä sähköpostitse kertomalla tutkimuksesta ja pyytämällä heitä osallistumaan siihen. Haastateltavien valintakriteereitä olivat: 1) työskentely lähijohdossa, keskijohdossa tai ylimmässä johdossa, 2) riittävä kokemus työskentelystä organisaatiossa (>1 vuotta) sekä 3) kokemusta digitalisaatiosta.

Haastattelut toteutettiin Microsoft Teamsilla, lukuun ottamatta yhtä haastattelua, joka toteutettiin puhelimitse yhteysongelmien vuoksi. Haastattelujen alussa kamera kytkettiin päälle, ja tutkija ja haastateltava jakoivat saman näkymän haastattelukysymyksistä. Yksi tutkija toteutti haastattelut. Haastattelut äänitettiin ja myöhemmin litteroitiin sanasta sanaan ja litteraatiot anonymisoitiin. Haastatteluita jatkettiin, kunnes saturaatio saavutettiin, eli haastatteluista nousi samansisältöisiä vastauksia (27). Haastattelut kestivät 25-60 minuuttia ja tuottivat yhteensä 850 minuuttia dataa. Litteroitua aineistoa kertyi 232 sivua (Verdana, fonttikoko 11, riviväli 1,15).

Tutkimukseen osallistui 21 perusterveydenhuollon johtajaa. Suurin osa johtajista oli naisia $(\mathrm{n}=19)$. Johtajat työskentelivät ylimmässä johdossa (4), keskijohdossa (8) ja lähijohdossa (9). Suurimmalla osalla johtajista (18) oli kliininen tausta (12 hoitaja- ja 6 lääkäritaustaista). Haastateltavien ikä vaihteli 35-65 vuoden välillä (keskiarvo 50 vuotta) ja johtamiskokemusta haastateltavilla oli 1-20 vuotta (keskiarvo 8 vuotta).

\section{TUTKIMUKSEN EETTISET LÄHTÖKOHDAT}

Tutkimuksen jokaisessa vaiheessa noudatettiin tieteellisen tutkimuksen eettisiä periaatteita (26). Tähän tutkimukseen saatiin Terveyden ja hyvinvoinninlaitoksen Tutkimuseettisen lautakunnan hyväksyntä [diaarinumero THL/2304/6.02.01/ 2020]. Lisäksi tutkimusluvat haettiin jokaisesta organisaatiosta ja haastateltavilta pyydettiin erillinen kirjallinen suostumus. Haastateltaville lähetettiin tiedote, jossa mainittiin tutkimukseen osallistumisen vapaaehtoisuus ja oikeus keskeyttää tutkimuksen osallistuminen missä vaiheessa tahansa. Lisäksi haastateltavilla on ollut mahdollisuus perehtyä tietosuojailmoitukseen. Haastattelujen nauhoitus perustui haastateltavien lupaan ja nauhoitukset olivat vain tutkijoiden käytössä. Tutkimustulokset on raportoitu siten, ettei yksittäisiä haastateltavia voida tunnistaa.

\section{AINEISTON ANALYYSI}

Aineisto analysoitiin induktiivisella sisällön analyysilla, jonka tarkoituksena oli saada kuvailevaa tietoa tutkimusaiheesta aineiston ehdoilla. Aineiston analysointiin osallistui kaksi tutkijaa, jotka etsivät samankaltaisuuksia ja eroavaisuuksia analyyseistään muodostaen keskustellen lopullisen analyysin. Analyysi tehtiin kummankin tutkimuskysymyksen osalta erikseen. Aineisto luettiin useaan otteeseen läpi, minkä jälkeen siitä poimittiin tutkimuskysymyksiä vastaavat alkuperäisilmaisut, jotka pelkistettiin. Analyysiyksikkönä käytettiin ajatuskokonaisuutta. Sisällöllisesti samaa tarkoitusta vastaavat pelkistetyt ilmaukset ryhmiteltiin samaan alakategoriaan ja samansisältöiset alakategoriat yhdistettiin kategorioiksi. Samansisältöisistä kategorioista muodostettiin yläkategorioita. (27.) Analysointiprosessista esitetään esimerkki taulukossa 1.

\section{TULOKSET}

\section{KORONAVIRUSPANDEMIAN VAIKUTUKSET DIGITAALISEEN TYÖKULTTUURIIN}

Koronaviruspandemian vaikutukset digitaaliseen työkulttuuriin liittyivät digitaalisen työkulttuurin kehittymiseen, muutokseen työnluonteessa sekä työyhteisön muutosvalmiuteen. Yläkategorioita muodostui kolme, jotka muodostuivat kuudesta kategoriasta ja 28 alakategoriasta (Taulukko 2).

Johtajat kokivat, että koronaviruspandemia johti digitaalisen työkulttuurin kehittymiseen, johon sisältyi uudet digitaaliset työtavat ja digitaalinen muutos. Uudet digitaaliset työtavat ilmenivät lisääntyneenä etätyön, -kokouksien, -koulutusten ja -palvelujen määränä, useiden digitaalisten työkalujen käyttöönottamisena, työn monipuolistumisena ja uusien työtapojen opetteluna, joiden perehtymiseen työntekijöillä oli vastuu. Joitakin tehtäviä alettiin hoitamaan etätyönä ja kokoukset siirrettiin suurilta osin sähköisille alustoille, kuten Teamsiin. Myös koulutuksia alettiin järjestää entistä enemmän etänä. Johtajien mukaan työntekijät kokivat etätyön pääsääntöisesti mieluisana. Sähköisten etäpalvelujen tarjoaminen lisääntyi ja esimerkiksi asiakkaita hoidettiin aikaisempaa enemmän etänä digitaalisia välineitä hyödyntäen ja puhelimen kautta. Useita uusia digitaalisia työkaluja otettiin käyttöön ja jo käytössä olevan digitalisaation käyttöä 
Taulukko 1. Esimerkki sisällönanalyysiprosessin etenemisestä.

\begin{tabular}{|c|c|c|c|}
\hline Pelkistetty ilmaus & Alakategoria & Kategoria & Yläkategoria \\
\hline $\begin{array}{l}\text { Nuoremmilla sujuvaa } \\
\text { Nuorilla näppärämpää } \\
\text { uusien asioiden } \\
\text { omaksuminen }\end{array}$ & $\begin{array}{l}\text { Nuorilla työntekijöillä } \\
\text { digitaalisten } \\
\text { työvälineiden käyttö } \\
\text { sujuvampaa }\end{array}$ & \multirow[t]{8}{*}{$\begin{array}{l}\text { Erot työntekijöiden IT } \\
\text { valmiuksissa }\end{array}$} & \multirow[t]{8}{*}{$\begin{array}{l}\text { Työyhteisön } \\
\text { muutosvalmius }\end{array}$} \\
\hline $\begin{array}{l}\text { Sukupolvien välinen } \\
\text { ero tekniikan } \\
\text { käyttötottumuksissa }\end{array}$ & $\begin{array}{l}\text { Osalla työntekijöistä } \\
\text { haasteita }\end{array}$ & & \\
\hline Erot IT-valmiuksissa & & & \\
\hline $\begin{array}{l}\text { Työntekijät eri tasolla } \\
\text { digitalisaation kanssa }\end{array}$ & & & \\
\hline $\begin{array}{l}\text { Kuormittaa osaa } \\
\text { työntekijöistä, joilla } \\
\text { alhainen IT-osaaminen }\end{array}$ & & & \\
\hline $\begin{array}{l}\text { Ammattilaiset mielellään } \\
\text { auttavat }\end{array}$ & $\begin{array}{l}\text { Kokeneemmat } \\
\text { työntekijät auttavat } \\
\text { vähemmän kokeneita }\end{array}$ & & \\
\hline $\begin{array}{l}\text { Uudenlainen sukupolvien } \\
\text { ylittävä toimintakulttuuri }\end{array}$ & & & \\
\hline Opastaminen ja auttaminen & & & \\
\hline
\end{tabular}

tehostettiin. Edellä mainitut muutokset muuttivat työtä monipuolisemmaksi, mutta vaativat uusien työtapojen ja tietoteknisten laitteiden käytön opettelua.

"On muuttanut varmaan siis sillä mielellä, että näistä etäkokouksista on tullut ihan ja etäkoulutuksista on tullut ihan... semmoista peruskauraa, että se on ihan normaalia että ollaan etäkokouksessa, tai että ollaan... koulutuksessa, mikä ei meillä ollut siis kyllä todellakaan normaalia ennen.” (Keskijohto 4)

Digitaalinen muutos ilmeni vauhdittuneena digimuutoksena, työn kehittämisenä digitalisaation avulla ja digitalisaation mainittiin säilyvän koronaviruspandemian jälkeenkin. Työn kehittäminen digitalisaation avulla tarkoitti työyhteisössä uusien palvelujen suunnittelua ja pilotointia, palvelukokonaisuuksien luomista ja digitalisaation käytettävyyden ja toimivuuden arviointia. Johtavat kokivat, että saavutettu digitalisaatio tulee säilymään koronaviruspandemian jälkeenkin, esimerkiksi siten, että etätyön ja -kokousten suosio tulee säilymään myös jatkossa. "[...]vaikka toki jo ennen korona-aikakautta meillä oli suunnitelmissa lisätä sähköisiä palveluita ja ottaa käyttöön... vaikkapa videovastaanotot ja näin, mutta kyllä tämä korona-asia vauhditti ihan selkeästi semmoista digiloikkaa..." (Lähijohto 5)

Muutokset työn luonteessa ilmenivät muutoksena työssä tapahtuvassa kanssakäymisessä ja sujuvana etätyönä. Muutos työssä tapahtuvassa kanssakäymisessä sisälsi kasvokkaisen kanssakäymisen vähentymisen, kanssakäymisen siirtymisen digitaalisiin välineisiin, yhteisten tapaamisten pitämisen etäyhteyksin ja tiedottamisen muuttumisen sähköiseksi. Kanssakäymisen muutosta kuvattiin myös etänä toteutetun vuorovaikutuksen erilaisuuden, työssä tapahtuvan kanssakäymisen muuttumisen, fyysisten tapaamisten kaipaamisen sekä työkulttuurin etäisemmäksi muuttumisen näkökulmista. Kasvokkaisen kanssakäymisen vähentyminen tarkoitti fyysisten tapaamisten vähentymistä, suoran kontaktin puuttumista työkavereihin sekä työntekijöiden kohortointia. Kanssakäymisen siirtyminen digitaalisiin välineisiin ilmeni kommunikointina digitaalisia välineitä hyödyntäen. Esimerkiksi työyhteisössä tapahtuva epä- 
virallinen yhteydenpito siirtyi WhatsApp -sovellukseen ja sähköisiä pikaviestimiä alettiin hyödyntämään entistä enemmän myös konsultoinnissa. Myös yhteisiä tapaamisia järjestettiin etäyhteyksin. Tiedottamisen muuttuminen sähköiseksi tarkoitti sitä, että organisaatioiden informaatio muutettiin ensisijaisesti sähköiseen muotoon ja myös tiedonkulku tapahtui pääsääntöisesti sähköisessä muodossa. Johtajat kuitenkin kuvailivat tiedon liikkumiseen liittyviä haastetta, sillä kaikki tieto ei saavuttanut työntekijöitä sähköisesti.

"Koska kaikki tieto ei kuitenkaan ole esimerkiksi sähköpostin välityksellä, ikään kuin se viesti tavoittaa kaikki, mutta sitä ei ehkä lueta taikka mielletä sitten sieltä lukien.” (Lähijohto 6)

Vuorovaikutuksen erilaisuus etänä kattoi epävirallisen kanssakäymisen vähentymisen ja viestinnän puutteellisuuden verrattuna kasvokkain kohtaamiseen. Fyysisten tapaamisten kaipaamista kuvailtiin ihmiskontaktien kaipaamisena, jotka aiemmin olivat olleet työyhteisöissä tärkeä voimavara. Työssä tapahtuvan kanssakäymisen muuttuminen näkyi epävirallisen kanssakäymisen vähentymisenä, haasteena yhteishengen ylläpitämisessä ja epävirallisen vuorovaikutuksen vähenemisenä. Työkulttuurin kuvailtiin muuttuneen etäisemmäksi ja työ koettiin yksinäisemmäksi.

”Ehkä se on vienyt vähän erilleenkin, ei ole semmoista niin kuin aina yhdessä tai me-hengen suhteen tuonut haastetta, että kukakin on vähän hajallaan siellä sun täällä, osa kotona...” (Lähijohto 4)

Johtajat kuvasivat digitaalisten muutosten sujuvoittaneen työtä, ja muuttaneen työntekoa ketterämmäksi, joustavammaksi ja rauhallisemmaksi. Ketteryydellä tarkoitettiin esimerkiksi sitä, että kokouksia oli helppo järjestää etänä nopeallakin aikataululla ja työntekijät oli helppo saada etänä koolle:

" [...] se on aika ketterä että voidaan aika nopeasti ottaa porukka kasaan, on se sitten mikä tahansa porukka. Niin saadaan nopeasti mahtumaan kaikkien kalenteriin, koska ne on hyvin lyhyitä.” (Lähijohto 6)
Johtajien mukaan etäkokoukset koettiin tehokkaampina, sillä ne eivät vaatineet aikaa siirtymisiin paikasta toiseen. Johtajien mukaan digitaalisten työvälineiden kautta tehty työ koettiin joustavana ja rauhallisena. Johtajat kuvasivat myös, että lievissä flunssaoireissa, mutta työkuntoisena oli mahdollista tehdä työtä kotoa käsin digitaalisia työvälineitä hyödyntäen. Digitaalisilla työvälineillä tehdyn työn tekeminen antoi vapautta, mikä puolestaan mahdollisti työntekijöiden paremman työhyvinvoinnin.

Työyhteisön muutosvalmius näkyi työkulttuurin muutokseen liittyvinä asenteina ja eroina työntekijöiden IT-valmiuksissa. Työkulttuurin muutokseen liittyviin asenteisiin sisältyi muutoksen kuormitus, resilienssin tarve, muutosvastarinta digitaalisia työvälineitä kohtaan ja ajattelumallin muutos. Johtajat kuvailivat koronaviruspandemian aiheuttaman muutoksen kuormittavuutta siten, että henkilökunta oli stressaantunutta ja se taas vaikeutti uusien asioiden omaksumista. Koronaviruspandemian aiheuttamat muutokset työhön vaati voimavaroja työntekijöiltä, esimieheltä ja johdolta. Eräs johtaja kuvaili resilienssin tarvetta seuraavalla tavalla:

"[...] mutta oikeasti tämä korona vauhditti kaiken niin, että se tapahtui sillä tavalla ihan hirveän nopeina rysäyksinä...vaikka se vaati kyllä henkisesti henkilökunnalta ja kaikilta oikeasti aika paljon relienssitasoa kyllä mitattiin tässä hommassa hyvin vahvasti ja mitataan edelleenki.” (Ylin johto 3)

Johtajat havaitsivat muutosvastarintaa digitaalisia työvälineitä kohtaan. Työntekijöillä oli eroja muutokseen sopeutumisessa ja kaikki eivät olisi halunneet ottaa käyttöön uusia digitaalisia työvälineitä tai niiden käyttö tuntui jännittävältä. Johtajien kokemusten mukaan osa työntekijöistä ajatteli, että potilaan fyysinen kohtaaminen olisi aina parempi vaihtoehto ja diagnoosien tekeminen ilman fyysistä kontaktia tuntui hankalalta. Ajattelumallin muutos näkyi asenteiden muutoksena digitalisaatiota kohtaan ja koronapandemian myötä asenteen suhteen tapahtui harppaus. Etäpalveluiden potentiaali huomattiin ja johtajien mukaan työntekijät olivat valmiimpia digitalisaatiolle koronapandemianseurauksena.Myöstyöntekijöiden ymmärrys digitalisaation hyödyntämisestä lisääntyi koronapandemian aiheuttaman pakon edessä. 
Johtajat kuvailivat eroja työntekijöiden ITvalmiuksissa. Nuorilla työntekijöillä digitaalisten työvälineiden käyttö oli sujuvampaa kuin iäkkäämmillä työntekijöillä. Nuoret olivat mukana digitaalisessa muutoksessa innokkaasti ja uusien asioiden omaksuminen oli heille luontevampaa. Sukupolvien välinen ero näkyi tekniikan käyttötottumuksissa. Osalla työntekijöistä oli sen sijaan haasteita digitaalisten työvälineiden kanssa. Työntekijät, joilla oli alhainen IT-osaaminen, olivat johtajien mukaan kuormittuneita ja työskentelivät epämukavuusalueella. Johtajat kokivat, että tekniikan käytössä kokeneemmat työntekijät tarjosivat mielellään apua tekniikan kanssa vähemmän kokeneille kollegoille. Työntekijät auttoivat mielellään toisiaan ja yksi johtaja kuvailikin, että digitalisaation lisääntymisen myötä syntyi uudenlaisen sukupolvien ylittävän toimintakulttuuri, jossa nuoremmat työntekijät auttoivat iäkkäämpiä työntekijöitä digitalisaation ja tekniikan kanssa, kun taas iäkkäämmät työntekijät tarjosivat nuoremmille tukea kliinisessä työssä.

"[...] jos on niin nuori, että on diginatiivi, niin sitten tietenkin varmaan asioiden omaksuminen on helpompaa, mutta sitten kuitenkin, kun meillä on työntekijöitä, jotka ovat lähellä eläkeikää...” (Lähijohto 3)

"[...] nuoremmilta kollegoilta avun pyytäminen $[. .$.$] he ovat paljon taitavampia näissä tie-$ toteknisissä asioissa, niin he tulivat mielellään avuksi... Ja sitten taas me vanhemmat kollegat, seniorit, tottakai autoimme heitä potilastyössä, joka sitten taas on heille vaikeampaa. Ja tästä tuli semmoinen minusta aika hieno uudenlainen sukupolvien ylittävä toimintakulttuuri, jota ei ole aikaisemmin ollut." (Lähijohto 5)

Taulukko 2. Johtajien kokemukset koronaviruspandemian vaikutuksista digitaaliseen työkulttuuriin.

\begin{tabular}{lll}
\hline Alakategoria & Kategoria & Yläkategoria \\
\hline Etätyö & Uudet digitaaliset työtavat & Digitaalisen työkulttuurin \\
Etäkokoukset & & kehittyminen \\
Etäpalvelujen lisääntyminen & &
\end{tabular}

Useat uudet digitaaliset työkalut

Työn monipuolistuminen

Uusien työtapojen opettelu

Työntekijöiden vastuu perehtymiseen

Etätyön kokeminen mieluisana

Vauhdittunut digimuutos

Työn kehittäminen digitalisaation avulla

Digitalisaatio säilyy koronaviruspandemian

jälkeenkin

Kasvokkaisen kanssakäymisen vähentyminen

Kanssakäymisen siirtyminen digitaalisiin välineisiin

Yhteisten tapaamisten pitäminen etäyhteyksin

Tiedottaminen sähköiseksi

Vuorovaikutus erilaista etänä

Työssä tapahtuvan kanssakäymisen muuttuminen

Fyysisten tapaamisten kaipaaminen

Työkulttuurin muuttuminen etäisemmäksi

Työn ketteryys

Työn joustavuus ja rauhallisuus

Muutos kuormittaa

Resilienssin tarve

Digitaalisia työvälineitä kohtaan

muutosvastarintaa

Muuttuneet ajattelumallit

Nuorilla työntekijöillä digitaalisten työvälineiden käyttö sujuvampaa

Osalla työntekijöistä haasteita digitaalisten

työvälineiden kanssa

Kokeneemmat työntekijät auttavat

vähemmän kokeneita
Muutos työssä tapahtuvassa

kanssakäymisessä

Työn sujuvuus

Työkulttuurin muutokseen liittyvät asenteet

Työyhteisön muutosvalmius 


\section{KORONAVIRUSPANDEMIAN VAIKUTUKSET DIGITAALISEN TYÖKULTTUURIN JOHTAMISEEN}

Koronaviruspandemian vaikutukset digitaalisen työkulttuuriin johtamiseen liittyivät muutosjohtamiseen, johtajan työn luonteen muutokseen ja johtajien muutosvalmiuteen. Yläkategorioita muodostui kolme, jotka muodostuivat seitsemästä kategoriasta ja 20 alakategoriasta (Taulukko 3).

Muutosjohtaminen ilmeni digitaalisen muutoksen johtamisena sekä työntekijöiden tukemisena ja heidän koulutuksestansa huolehtimisena. Digitaalista muutosta johtaessaan johtajat veivät työntekijöille uusia digitalisaation perustuvia toimintatapoja, ja perustelivat näiden käyttöönottoa ja käyttöä työntekijöille. Johtajien mukaan koronapandemia helpotti digitalisaatioon liittyvää muutosta ja vähensi muutosvastarintaa, koska työntekijät ymmärsivät tilanteen pakonomaisuuden esimerkiksi etäpalvelujen tarjoamiseen siirtymisessä. Johtajat kokivat digitaalisen muutoksen johtamisen henkisesti haasteelliseksi, koska digitalisaatio sisälsi heille itselleenkin paljon uusia asioita, jotka täytyi opetella. Johtajat kokivat myös, että työnluonteen muutos tulee säilymään tarkoittaen esimerkiksi sitä, että etätyöskentely jää koronapandemian jälkeenkin ainakin jokseenkin pysyväksi työskentelytavaksi.

"[...] että aina on kaikki uusi ihmiselle on kovin luontaista tämmöinen vähän niin kuin vastarinta ja uuden pelko ja vastustus, ehkä just koronan hyvä puoli tuli, et se tuli vähän niin kuin pakosta, että jokainen ymmärsi että tämä on nyt tehtävä, et tämä ei ole vaihtoehto, että kaikki ramppaa täällä vastaanotolla. Niin siitä ei tarvinnut niin paljon neuvotella." (Lähijohto 4).

Johtajat tukivat työntekijöitä ja huolehtivat siitä, että työntekijät saivat koulutusta liittyen käyttöönotettaviin digitaalisiin ratkaisuihin. Työntekijöiden tukeminen ilmeni myös siten, että johtajat tukivat aktiivisesti työntekijöitä uusien työskentelytapojen kanssa. Johtajat esimerkiksi kannustivat ja tsemppasivat työntekijöitä, mutta he myös valvoivat etänä työskenteleviä työntekijöitä ja vaativat heitä käyttämään digitaalisia työkaluja. Johtajat myös kartoittivat työntekijöiden koulutus- ja perehdytystarpeita, mutta kokivat silti samalla, ettei kouluttamiseen ollut aikaa riittävästi keskellä koronapandemiaa.
”Ja olen sitä mieltä, että siihen on lähdetty aika helposti, että sen kun vain siirryttiin, että ei niin ehditty kouluttaa, eikä valmentautua siihen niin kuin olisi voinut.” (Keskijohto 7)

Johtajan työn luonteen muutokseen sisältyi etätyön johtaminen, johtajien ja työntekijöiden kanssakäymisen muutos ja tiukentunut työtahti. Etätyön johtamiseen sisältyi toisaalta etätyön mahdollistamista työntekijöille, mutta myös johtajan kyky luottaa työntekijöihin. Jotta johtajat kykenivät mahdollistamaan etätyön, tuli heidän huolehtia etätyöhön tarvittavien välineiden hankkimisesta sekä riittävien ohjeistusten antamisesta. Itse etäjohtamisen johtajat kokivat samanaikaisesti sekä haastavana että johtamista sujuvoittavana tekijänä. Vaikka etäjohtaminen koettiin haastavana, johtajat kokivat, että heidän työnsä sujuvoitui, sillä kokoukset mahdollistuivat ketterämmin digitaalisia työvälineitä käyttäen. Näin johtajat kykenivät paremmin aikatauluttamaan toimintaansa sekä viemään asioita eteenpäin.

"[...] lähiesimies on melkein pakko siellä läsnä olla, jotta se työyhteisö etenkin tuollaisessa osastomaailmassa toimii hyvin, eli sitä on vaikeampi etänä johtaa...” (Lähijohto 9)

"[...] että ei ole tullut sellaisia luottamusongelmia, tai että väki jättäisi töitä tekemättä.” (Lähijohto 4)

Koronaviruspandemia vaikutti johtajan ja työntekijöiden kanssakäymiseen, joka sisälsi työntekijöiden fyysisen tapaamisen puuttumisen, digitaalisen vuorovaikutuksen, suhteen ylläpitämisen työntekijöiden kanssa ja työyhteisön yhteisöllisyyden tukemisen. Johtajat eivät tavanneet työntekijöitään fyysisesti koronapandemiasta johtuen, mutta he kertoivat kuitenkin kaipaavansa fyysisiä tapaamisia työntekijöiden ja muiden johtajien kanssa. Johtajat kokivat, että etänä työntekijöiden tunteminen oli erilaista ja esimerkiksi uusien työntekijöiden tuntemaan oppiminen tuntui haastavammalta etätyötä tehdessä. Johtajat olivat usein työntekijöiden kanssa vuorovaikutuksessa digitaalisia työvälineitä käyttäen eli yhteydenpito tapahtui usein sähköisesti. Johtaminen etäkokouksilla ja kamerattomuus aiheuttivat johtajille tunteen, ettei kuulijoita ole ja että pelkästään johtajan äänen kuuleminen ei ollut johtajien ko- 
Taulukko 3. Johtajien kokemukset koronaviruspandemian vaikutuksista digitaalisen työkulttuurin johtamiseen.

\begin{tabular}{|c|c|c|}
\hline Alakategoria & Kategoria & Yläkategoria \\
\hline $\begin{array}{l}\text { Uusien toimintatapojen vieminen } \\
\text { työntekijöille } \\
\text { Koronaviruspandemia helpottanut } \\
\text { digimuutosta } \\
\text { Henkisesti haasteellista } \\
\text { Muutos säilyy koronaviruspandemian } \\
\text { jälkeenkin }\end{array}$ & $\begin{array}{l}\text { Digitaalisen muutoksen } \\
\text { johtaminen }\end{array}$ & Muutosjohtaminen \\
\hline $\begin{array}{l}\text { Tuen antaminen uuteen työtapaan } \\
\text { Työntekijöiden koulutuksesta } \\
\text { huolehtiminen }\end{array}$ & $\begin{array}{l}\text { Työntekijöiden tukeminen ja } \\
\text { koulutuksesta huolehtiminen }\end{array}$ & \\
\hline $\begin{array}{l}\text { Etätyön mahdollistaminen } \\
\text { Etätyön johtaminen haastavampaa } \\
\text { Luottamus työntekijöihin } \\
\text { Johtaminen sujuvampaa }\end{array}$ & Etätyön johtaminen & Johtajan työn luonteen muutos \\
\hline $\begin{array}{l}\text { Työntekijöiden fyysisten } \\
\text { tapaamisen puuttuminen } \\
\text { Digitaalinen vuorovaikutus } \\
\text { Suhteen ylläpitäminen työntekijöiden kanssa } \\
\text { Työyhteisön yhteisöllisyyden tukeminen }\end{array}$ & $\begin{array}{l}\text { Johtajan ja työntekijöiden } \\
\text { kanssakäyminen }\end{array}$ & \\
\hline $\begin{array}{l}\text { Työtahti nopeatempoisempaa } \\
\text { Lisääntynyt kokousten määrä }\end{array}$ & Tiukentunut työtahti & \\
\hline $\begin{array}{l}\text { Vaatii innokkuutta } \\
\text { Vaatii kiinnostusta }\end{array}$ & Johtajien motivaatio & Johtajien muutosvalmius \\
\hline $\begin{array}{l}\text { Riittämätön IT-osaaminen } \\
\text { Työntekijät tukevat johtajaa }\end{array}$ & $\begin{array}{l}\text { IT-osaaminen ja siihen saatu tuki } \\
\text { työntekijöiltä }\end{array}$ & \\
\hline
\end{tabular}

kemusten mukaan työntekijöille riittävää. Jotta johtajat kykenivät ylläpitämään suhdetta työntekijöiden kanssa, he joutuivat pohtimaan uusia yhteydenpidon keinoja, johon myös työntekijät osallistuivat. Johtajan ja työntekijöiden välisen suhteen ylläpitäminen henkilökohtaisena ja se, etteivät työntekijät kokisi jääneensä yksin etätyössä mietitytti johtajia. Kasvotusten jutteleminen koettiin helpompana ja etänä muun keskustelun kerrottiin jäävän vähemmäksi. Tämä loi johtajien mielestä haasteen työntekijöiden kuulluksi tulemiselle. Johtajien mukaan työntekijät kaipasivat myös läsnäoloa johtajalta. Johtajat kokivat tehtäväkseen työyhteisön yhteisöllisyyden tukemisen, joka tarkoitti esimerkiksi yhteishengen ylläpitämistä. Haasteena oli sosiaalinen läsnäolo, työyhteisöelämän ja hyvän työilmapiirin ylläpitäminen etänä.

"Että ehkä se on se semmoinen just sosiaalisen läsnäolon ja semmoisen yhteishengen suh- teen ne suuremmat haasteet, kuin sitten se, että se ihan performanssi siinä suoritteiden tekemisessä, on se sitten reseptin uusintaa tai puhelinsoittoa tai sen tyyppistä. Että ihmisillä on mahdollisuus kysyä ja konsultoida, kertoa, mitä kuuluu, tämän tyyppinen työyhteisöelämän ylläpito, siinä on varmaan se johtamisen haasteet enemmänkin kuin valvoa sitä, että tuleeko suoritteita sieltä etähommista." (Lähijohto 4)

Koronaviruspandemia aiheutti sen, että etäkokouksia oli enemmän ja näin myös johtajien työtahti oli tiukempi, sillä esimerkiksi paikasta toiseen siirtymisiin ei mennyt niin paljon aikaa. Tiukentunut työtahti aiheutti sen, että johtajat esimerkiksi pitivät taukojaan tietokoneen äärellä ja työpäivät sisälsivät paljon kokouksia. 
"Ja se on tietysti ajankäytön suhteen vaikuttanu niin, että nyt kun itsellä on paljon kaikenlaisia kokouksia ni nyt siihen matkaan ei kulu aikaa ja se päivä saadaan kyllä tykitettyä niitä kokousia sitten varsin täyteen.” (Keskijohto 8)

Johtajien muutosvalmiuteen liittyi johtajien motivaatio sekä se, että johtajat kokivat puutteita ITosaamisessaan, johon he kuitenkin saivat tukea työntekijöiltä. Johtajat tarvitsivat motivaatiota kiinnostusta ja innostusta digitalisaation käyttöön. Osa johtajista koki, että heidän IT-taitonsa eivät olleet riittävät ja he tunsivat epävarmuutta ja huolta omasta osaamisestaan. Johtajien tuli ensin itse opetella uusia asioita, jotta he pystyivät opettamaan työntekijöitä, jotka tarvitsivat tukea tekniikan käytössä. Johtajat kertoivat myös työntekijöiden tukeneen heitä IT-asioissa, ja apua he olivat saaneet erityisesti nuoremmilta työntekijöiltä.

" [...] se semmoinen [johtajan] tietoteknisten taitojen taso ei välttämättä ole niin heti siinä valmiudessa ottaa nämä kaikki käyttöön. Ja se tietyllä tavalla semmoinen, ei nyt suorastaan pelko, mutta kuitenkin se huoli siitä, että osaanko minä oikeasti toimia tässä, niin kyllä se on oikeastaan aika suuri. ” (Lähijohto 5)

\section{POHDINTA}

Tutkimus tuotti uutta tietoa perusterveydenhuollon johtajien kokemuksista koronaviruspandemian vaikutuksista digitaaliseen työkulttuuriin ja sen johtamiseen. Tutkimuksessa havaittiin koronaviruspandemian aiheuttaneen nopean digimuutoksen terveydenhuollon organisaatioihin, mikä muutti organisaatioiden työkulttuuria. Tutkimuksen tuloksissa korostui varsinkin digitaalisen työkulttuurin kehittyminen perusterveydenhuollossa, johon sisältyi uudet työtavat, kuten etätyö. Verrattuna muihin toimialoihin etätyö ei ole ollut terveydenhuollossa yhtä yleistä. Tutkimuksemme löydös lisääntyneestä etätyöstä on kuitenkin yhtenäinen aiemman tutkimustiedon kanssa, jonka mukaan etätyö on keino koronaviruksen leviämisen ehkäisemiseksi (28). Suomessa etätyö on yleistynyt voimakkaasti jo ennen koronaa (29), ja tämä tutkimus osoitti etätyön lisääntymisen myös tapahtuneen perusterveydenhuollossa. Myös Eurofoundin (30) vertailevan selvityksen perusteella tiedetään, että Suomi oli koronakeväänä 2020 Euroopan kärkimaa etätyön yleisyydessä.

Tämän tutkimuksen mukaan etätyö mahdollisti perusterveydenhuollon työntekijöiden työn tekemisen flunssaoireisena, mutta työkuntoisena. Aiemman tutkimustiedon mukaan digitaalisten ratkaisujen käyttö mahdollistaa karanteeniin asetettujen, mutta oireettomien terveydenhuollon työntekijöiden työskentelyn kotoa käsin (6). Tämän tutkimuksen tulokset osoittivat johtajien kannustavan työntekijöitä etätyöhön. Aiemman tutkimuksen mukaan etätyöskentely vaatii tukea johtajalta ja tuki lisää työtyytyväisyyttä ja vähentää psykologista rasitusta (31). Tulostemme mukaan koronaviruspandemia aiheutti etäpalvelujen tarjoamisen lisääntymisen nopealla aikataululla. Koronaviruspandemian on aikaisemmissa tutkimuksissa todettu lisäävän etähoitoa (11) ja etänä toteutettavien palveluiden määrän kasvua (32).

Tässä tutkimuksessa johtajat kokivat, että työntekijät olivat kuormittuneita koronaviruspandemian aiheuttamasta muutoksesta ja kokivat stressiä. Myös aiempi tutkimus on osoittanut koronaviruspandemian aiheuttaneen useita muutoksia, jotka ovat lisänneet terveydenhuollon työntekijöiden stressiä (11). Tietojärjestelmät ja niihin kytkeytyvät tekniset ongelmat ylipäätään lisäävät terveydenhuollon työntekijöiden kokemaa stressiä, jota puolestaan helpottaa tietojärjestelmien käyttäjäystävällisyys (33). Aiemmat tutkimukset osoittavat, että Suomessa tietojärjestelmiin liittyvä stressi on lisääntynyt terveydenhuollossa 2000-luvulla ja siitä on muodostunut yksi keskeinen kuormitustekijä terveydenhuollon ammattilaisille $(34,35)$. Koronaviruspandemian aikana digitaalisia työvälineitä on otettu käyttöön nopeutetulla tahdilla, joten voi olla, ettei niiden käytettävyyteen ole aikataulun vuoksi ehditty kiinnittää huomiota.

Tämän tutkimuksen tulokset osoittavat, että viestintään käytettiin sähköisiä alustoja ja työntekijät pitivät yhteyttä toisiinsa pikaviestintäpalveluissa. Aiemman tutkimuksen mukaan etätyössä säännöllinen viestintä johtajien ja heidän tiiminsä välillä sekä työntekijöiden kesken on tärkeää ja se auttaa vähentämään eristyneisyydestä aiheutuvia negatiivisia vaikutuksia (28). Tässä tutkimuksessa tuli esille tiedonkulun muuttuminen yhä enemmän sähköiseksi, josta seurasi puolestaan haasteita tiedon saavutettavuudessa työn- 
tekijöille. Etäviestinnän haasteiksi on todettu aiemmassa tutkimuksessa tiedonkulkuun liittyvä kiire, vaikeus poimia oleellinen suuresta infotulvasta, hitaus ja se, että tieto ei kulje lainkaan (36). Sähköisessä tiedottamisessa olisi hyvä käyttää erilaisia muotoja, kuten pelkän tekstin sijaan myös ääntä ja kuvia. Suuret tietomäärät, jotka on esitetty vain yhdellä tavalla, voivat ylikuormittaa ja johtaa vähemmän tehokkaaseen viestintään. (37).

Tässä tutkimuksessa digitaalisen muutoksen johtamiseen liittyi työntekijöiden rohkaiseminen muutoksessa pysymiseen ja tuen antaminen uusiin digitaalisiin työskentelytapoihin. Aiemmassa tutkimuksessa hyvä johtajuus, joka kannusti kulttuurimuutokseen koronapandemian aikana, nähtiin koronaviruspandemian aiheuttamana positiivisena muutoksena (11). Tutkimuksessamme johtajat kokivat muuttuneen tilanteen johtamisen henkisesti haastavana. Aiemman tutkimustiedon mukaan johtajat voivat kokea suurtakin painetta digitaalisen muutoksen johtamisessa, sillä heidän on tuettava terveydenhuollon työntekijöitä muutoksessa, järjestettävä työnkulku ja varmistettava uusien sähköisten palvelujen riittävä laatu (18).

Tutkimuksemme tuloksissa nousi esiin, että etänä työntekijöiden tapaaminen oli erilaista ja esimerkiksi johtajista tuntui haastavalta oppia tuntemaan uudet työntekijät. Aiemman tutkimustiedon mukaan etäjohtaminen vaikeuttaa ihmissuhteiden luomista ja ylläpitämistä, mikä on tärkeä osa johtamista (38). Etänä viestintä on muodollisempaa ja vastavuoroisuus puuttuu, jolloin tuttuutta ei synny (36). Etäjohtajien tulisi pyrkiä kuitenkin tuntemaan tiiminsä jäsenet yksilöinä (37). Tämän tutkimuksen tuloksien mukaan johtajat joutuivat pohtimaan myös keinoja, joilla suhteen työntekijöihin voi säilyttää henkilökohtaisena.

Tutkimukseemme osallistuvien johtajien mukaan työntekijät kaipasivat heiltä läsnäoloa. Tämä tulos tukee aiempaa löydöstä, jossa terveydenhuollon organisaatiossa sähköisen viestinnän käyttö on saanut työntekijät toivomaan johtajan tapaamista kasvotusten (19). On myös tavallista, että työntekijöiden mielestä etänä olo ei korvaa läsnäoloa ja johtajan odotetaan tulevan paikan päälle (36). Johtajien on tärkeää olla sosiaalisesti läsnä etänä toimivia tiimejä johtaessaan (37). Tutkimuksemme mukaan, huolimatta siitä, että vaikka johtajat kävivät vähemmän kasvokkaista kanssakäymistä työntekijöiden kanssa, johtajat pystyivät luottamaan työntekijöiden työpanokseen, kun työntekijä työskenteli etänä. Etätyöskentelyssä luottamuksen merkitys näyttäisi korostuvan myös aikaisemmissa tutkimuksissa (37, 39). Kuitenkin luottamuksellisen suhteen säilyminen ja syntyminen edellyttävät säännöllistä kanssakäymistä ja mielellään myös satunnaisia kasvokkaisia tapaamisia (39).

Tulostemme mukaan johtajien riittämätön IT-osaaminen aiheutti epävarmuutta ja huolta johtajissa. Aiempi löydös osoittaa, että osa terveydenhuollon johtajista kokee tarvitsevansa koulutusta IT- taitoihinsa (18). Johtajien koulutus liittyen terveydenhuollon digitaalisten ohjelmien, sovellusten ja tieto- ja viestintätekniikan käyttöön on puutteellista (38). Johtajat oppivat usein teknisiä taitoja työnsä lomassa itseoppimalla (40). Johtajat tarvitsevat koulutusta, mentorointia ja tukea teknologian hyödyntämiseen työssään. $(38,40)$. Tämän tutkimuksen mukaan johtajat kokivat, että heidän tulee opetella ensin itse käyttämään tietotekniikkaa, jotta he voivat ohjeistaa sen käyttöä edelleen työntekijöille. Aiemman tutkimustiedon mukaan johtajien asenteet ja taidot tietototekniikan käytössä heijastuvat työntekijöihin ja johtajien toimiminen esimerkkinä aktiivisena tietotekniikan käyttäjänä on merkittävää (19).

Tässä tutkimuksessa nousivat esiin myös työntekijöiden erot IT-taidoissa. Aiemmassa tutkimuksessa on tullut esille, että johtajat ovat enemmän huolissaan työntekijöiden IT-taidoista, kuin omistaan (19). Tässä tutkimuksessa johtajat toivat esiin huolen erityisesti vanhempien työntekijöiden riittämättömästä IT-osaamisesta, mutta kertoivat kuitenkin nuorempien työntekijöiden omaavan hyvät IT-taidot ja nuorten auttavan mielellään vanhempia työntekijöitä IT:n käytön kanssa. Johtajat mainitsivat tehtäväkseen huolehtia työntekijöiden kouluttamisesta, mutta siihen ei ollut koronapandemian aiheuttaman paineen vuoksi riittävästi aikaa. Aiemman tutkimustiedon mukaan johtajien tulee tunnistaa työntekijöiden IT-osaaminen ja mahdolliset puutteet siinä (19). Digitaalisten palveluiden menestyksekkäässä käyttöönotossa koulutuksen tarjoamista työntekijöille pidetään tärkeänä tekijänä (20).

Tutkimuksemme osoittaa, että johtajien kokemusten mukaan koronaviruspandemian aiheuttamat digitalisaatioon liittyvät muutokset, ku- 
ten digitalisaation lisääntynyt käyttö ja etätyö, tulivat jäädäkseen perusterveydenhuollon organisaatioihin. Aiemman tutkimuksen mukaan koronaviruspandemian aiheuttamat muutokset työn digitaalisuudessa ovat muuttaneet peruuttamattomasti digitalisaation ja digitaalisten palveluiden asemaa Yhdysvaltojen terveydenhuoltojärjestelmässä (6). Paloniemen (7) mukaan koronaviruspandemialla saattaa olla merkittävä vaikutus digitaalisen transformaation edistäjänä julkisen sektorin toiminnassa myös Suomessa. Tutkimuksemme tulosten perusteella näyttääkin siltä, että digitalisaatioon liittyvien muutosten tuleminen jäädäkseen muuttaa pysyvästi perusterveydenhuollossa tehtävää työtä, organisaatioita sekä näiden kautta myös asiakkaille tarjottavia palveluita.

\section{LUOTETTAVUUS}

Tutkimuksen luotettavuutta voidaan arvioida uskottavuuden, varmuuden, vahvistettavuuden, autenttisuuden ja siirrettävyyden kriteereillä (41). Tutkimuksen uskottavuutta pyrittiin parantamaan valitsemalla haastateltavat harkinnanvaraisesti tietyin kriteerein, joka auttoi tarkoituksenmukaisen aineiston saamista. Lisäksi aineiston otoskoko arvioitiin riittävän suureksi, sillä se saturoi, eli haastatteluista nousi samasisältöisiä vastauksia. Tutkimuksen varmuutta lisää kahden tutkijan osallistuminen aineiston analyysiin, mikä mahdollisti luokittelulogiikan tarkistuksen. Vahvistettavuutta pyrittiin parantamaan kirjaamalla selkeästi tutkimusprosessin kulku. Suorien lainausten käyttö tukee tutkimuksen autenttisuutta. Tulosten siirrettävyyttä on pyritty parantamaan ottamalla haastateltaviksi eri johtotasoihin kuuluvia johtajia sekä kuvaamalla haastateltavien taustatiedot selkeästi. Tulosten laajempaa siirrettävyyttä rajoittaa tutkimuksen kohdistuminen perusterveydenhuollon kontekstiin, jolloin tutkimustulokset voivat soveltuvin osin olla siirrettävissä vastaaviin perusterveydenhuollon toimintayksiköihin.

\section{JOHTOPÄÄTÖKSET}

Johtopäätöksenä voidaan todeta, että koronaviruspandemia muutti nopeasti perusterveydenhuollon digitaalista työkulttuuria ja digitaalinen muu- tos nähdään pysyvänä. Digitaalisten työvälineiden käytön lisääntyminen muutti erityisesti työssä tapahtuvaa kanssakäymistä. Digitaalinen muutos voi stressata ja kuormittaa työntekijöitä, jota voidaan puolestaan helpottaa siten, että johto tarjoaa tukensa työntekijöille. Johtajien tulisi kiinnittää digitaalisia työvälineitä käytettäessään huomiota suhteiden säilyttämiseen ja luottamuksen syntymiseen työntekijöiden kanssa. Niin terveydenhuollon työntekijöiden, kuin johtajien ITosaamiseen ja siihen liittyvään koulutukseen on tärkeää kiinnittää huomiota. Tuloksia voidaan hyödyntää digitaalisten terveyspalveluiden ja työkulttuurin kehittämisessä, johtamisessa, koulutuksessa ja työyhteisöjen muutosvalmiuden tukemisessa.

Jatkossa digitaalisen työkulttuurin muutosta voisi tutkia työntekijöiden näkökulmasta sekä selvittää, kuinka koronaviruspandemia ja nopealla tahdilla lisääntyneet digitaaliset työvälineet ovat vaikuttaneet heidän työhyvinvointiinsa. Lisäksi olisi tärkeä tutkia johtajan ja työntekijöiden välistä kanssakäymistä digitaalisia työvälineitä käyttäen sekä sitä, kuinka johtaja voi toiminnallaan etätyössä edistää kanssakäymistä työntekijöiden kanssa, siten, että luottamuksellinen suhde muodostuu ja säilyy. Lisäksi tutkimustietoa tarvitaan myös pandemian aiheuttaman digitaalisen muutoksen pysyvyydestä.

\section{KIITOKSET:}

Kiitämme rahoittajia tutkimuksen mahdollistamisesta, tutkimukseen osallistuneita tiedonantajia sekä vertaisarvioijia.

\section{RAHOITTAJAT:}

Tutkimus tehtiin osana DigiIN -hanketta, jota tuki Strategisen tutkimuksen neuvosto [päätösnumero 327145] sekä Valtion lisätalousarviossa Covid 19-tutkimukseen osoitettu THL:n koordinoima rahoitus.

\section{KIRJOITTAJIEN KONTRIBUUTIOT:}

Tutkimuksen suunnittelu: AR, EL, AK, TH aineistonkeruu: EL, aineiston analyysi: AR, EL, käsikirjoituksen kirjoittaminen: AR, käsikirjoituksen kommentointi: EL, TH, AK, OK 
The crisis by the coronavirus pandemic has shaped work culture in healthcare, which has ever increasingly resorted to digital solutions to prevent the spread of the coronavirus. There has been little research on the impact of the coronavirus pandemic on digital work culture and its leadership, and information is needed, for example, for the continuous assessment and improvement of healthcare organizations.

The aim of this descriptive qualitative research is to examine primary health care managers' experiences on the effects of the coronavirus pandemic on digital work culture and its leadership. The data for research was collected through semi-structured individual interviews of primary health care managers $(n=21)$ in three municipalities and one joint municipal authory. Inductive content analysis was implemented for the analysis of data.

The results suggest that the effects of coronavirus pandemic concerning digital work culture related to evolution of digital work culture, transformation in the nature of work, and readiness for change. The effects of coronavirus pan- demic concerning the leadership of digital work culture in turn related to change management, transformation of leaders' work, and leaders' readiness for change.

As a conclusion, our results suggest that coronavirus pandemic rapidly and permanently changed the digital work culture in primary care. Especially the increased use of digital tools transformed the interaction at work. Leaders support seemed fundamental in digital transformation, which employees experienced stressful. In the future leaders should pay more attention to maintaining relationships with employees when leading remotely. In addition, organizations should invest in providing IT skills training for both staff and management. The results of this study can be utilized when developing digital health services and work culture, leadership, training and supporting change readiness. Keywords: Digitalization, leadership, work culture, COVID-19

Saapunut (11.03.2021)
Hyväksytty (06.07.2021)

\section{LÄHTEET}

(1) Terveyden- ja hyvinvoinnin laitos. Koronavirus COVID-19 2021. Luettu 20.2.2021. https:// thl.fi/fi/web/infektiotaudit-ja-rokotukset/tauditja-torjunta/taudit-ja-taudinaiheuttajat-a- o/ koronavirus-covid-19

(2) WHO. WHO Director-General's opening remarks at the media briefing on COVID-19 - 11 March 2020. Luettu 30.1.2021. https:// www.who.int/director-general/speeches/detail/ who-director- general-s-opening-remarks-at-themedia-briefing-on-covid-19---11-march-2020

(3) WHO. COVID-19 Strategy Up Date 2020. Luettu 30.1.2021. https://www.who.int/ publications/m/item/covid-19-strategy-update

(4) Gunasekeran DV, Tham Y-C, Ting DSW, ym. Digital health during COVID-19: lessons from operationalising new models of care in ophthalmology. The Lancet Digit Health 2021;3:e124-134.

doi: 10.1016/S2589-7500(20)30287-9

(5) Chudasama YV, Gillies CL, Zaccardi F, ym. Impact of COVID-19 on routine care for chronic diseases: A global survey of views from

healthcare professionals. Diabetes Metab Syndr 2020;14:965-967.

doi: 10.1016/J.DSX.2020.06.042

(6) Mann DM, Chen J, Chunara R, ym. COVID-19 transforms health care through telemedicine: Evidence from the field. J Am Med Inform Assoc 2020;27(7):1132-1135.

doi: 10.1093/jamia/ocaa072.

(7) Palomäki R. Julkisen hallinnon haasteita ja mahdollisuuksia digitaalisessa transformaatiossa. Hallinnon tutkimus 2020;39(3):173-187. doi: https://doi.org/10.37450/ht.100036

(8) Bartsch S, Weber E, Büttgen, ym. A Leadership matters in crisis-induced digital transformation: how to lead service employees effectively during the COVID-19 pandemic. J Serv Manag 2020;32(1):71-85 doi: 10.1108/JOSM-05-2020-0160

(9) Gjellebak C, Svensson A, Bjorkquist C, ym. Management challenges for future digitalization of healthcare services. Futures 2020;124:102636. doi: https://doi.org/10.1016/j. futures.2020.102636 
(10) Gangakhedkar GR, Solanki SL. Impact of the COVID-19 pandemic on anesthesiologists in India: A cross-sectional online survey of the practices, preparedness, and mind-set. J Anaesthesiol Clin Pharmacol 2020;36(3):331336. doi: 10.4103/joacp.JOACP_375_20

(11) Pilar A, Gravel S B, Croke J, ym. Coronavirus Disease 2019's (COVID-19's) Silver LiningThrough the Eyes of Radiation Oncology Fellows. Avd Radia Oncol 2021;6:1:100527 doi: 10.1016/j.adro.2020.07.004

(12) André B, Sjøvold E, Rannestrad T. ym. The impact of work culture on quality of care in nursing homes - a review study. Scand J Caring Sci 2013;28:3:449-457. doi: 10.1111/scs.12086

(13) Vazquez CE. Successful work cultures: recommendations for leaders in healthcare. Leadersh Health Serv 2019;32(2)296-308. doi: 10.1108/LHS-08-2018-0038

(14) Konttila J, Siira H, Lahtinen M, ym. Healthcare professionals' competence in digitalisation: A systematic review. J Clin Nurs 2018;28(56):745-761. doi: 10.1111/jocn. 14710

(15) Schlicht L, Wendsche J, Lehrke L, ym. Nursers' attitudes towards occupational transformation processes brought about by digital care technologies. Curr Dir Biomed Eng 2020;6(3):20203160 doi: https://doi. org/10.1515/cdbme-2020-3160

(16) Petrakaki D, Klecun E \& Cornford T. Changes in healthcare professional work afforded by technology: The introduction of national electronic patient record in an English hospital. Organization 2016;23(2):206-226. doi: $10.1177 / 1350508414545907$

(17) André B, Sjøvold E. What characterizes the work culture at a hospital unit that successfully implements change - A correlation study. BMC Health Serv Res 2017;17;486. doi 10.1186/s12913- 017-2436-4

(18) Kujala S, Heponiemi T \& Hilama P. Clinical Leaders' Self-Perceived eHealth Competencies in the Implementation of New eHealth services. Stud Health Technol Inform 2019;264:12531257. doi: 10.3233/SHTI190427

(19) Lammintakanen J, Saranto K, Kivinen T. Use of Electronic Information Systems in Nursing Management. Int J Med Inform 2010;79(5):324331. doi: 10.1016/j.ijmedinf.2010.01.015

(20) Kho J, Gillespie N, Martin-Khan M. A systematic scoping review of change management practices used for telemedicine service implementations. BMC Health Serv Res 2020;20:815. doi: https://doi.org/10.1186/ s12913-020-05657-w

(21) Maniam VA. Analysis of Workplace Learning Opportunities Experienced by Managers. Procedia Soc Behav Sci 2012;65:815-820. doi: 10.1016/j.sbspro.2012.11.204

(22) Glaser L, Fourné SPL, Elfring T. Achieving strategic renewal: the multi-level influences of top and middle managers' boundary-spanning. Small bus Econ 2015;45:305-327. doi: https:// doi.org/10.1007/s11187-015-9633-5
(23) Varsi C, Ekstedt M, Gammon D, ym. Middle managers' experiences and role in implementing an interactive tailored patient assessment eHealth intervention in clinical practice. Comput Inform Nurs 2015;Jun:33:249-257. doi: 10.1097/CIN.0000000000000158

(24) Kelly LA, Wicker TL, Gerkin RD. The relationship of training and education to leadership practices in frontline nurse leaders. J Nurs Adm 2014;44(3):158-163. doi: 10.1097/NNA.0000000000000044

(25) Sosiaali- ja terveysministeriö. Hallituksen kärkihankkeessa kehitetty uusi sähköinen sotepalvelu OmaOlo siirtyy SoteDigi-yhtiöön 2018. Luettu 24.2.2021. https://stm.fi/-/hallituksenkarkihankkeessa-kehitetty-uusi-sahkoinen-sotepalvelu-omaolo-siirtyy-sotedigi-yhtioon

(26) Tutkimuseettinen neuvottelukunta. Ihmiseen kohdistuvan tutkimuksen eettiset periaatteet ja ihmistieteiden eettinen ennakkoarviointi Suomessa. Tutkimuseettisen neuvottelukunnan ohje 2019. Luettu 6.3.2021. https://www.tenk. fi/sites/tenk.fi/files/Ihmistieteiden_eettisen_ ennakkoarvioinnin_ohje_2019.pdf?_g $\mathrm{a}=2.152439344 .82887756 .1615165260$ 1238563927.1615165260

(27) Kyngäs H. Inductive Content Analysis. Kirjassa Kyngäs H, Mikkonen K, Kääriäinen M. In The Application of Concent Analysis in Nursing Science Research. Springer International Publishing 2020;13-21. doi: /https://doi. org/10.1007/978-3-030-30199-6

(28) Oakman J, Kinsman N, Stuckey R, ym. A rapid review of mental and physical health effects of working at home: how do we optimise health? BMC Public Health 2020;20:1825. doi: https:// doi.org/10.1186/s12889-020-09875-z

(29) Työ- ja elinkeinoministeriö Työolobarometri -ennakkotiedot. Työ- ja elinkeinoministeriön julkaisuja 2021;18 Luettu 15.5.2021. https:// julkaisut.valtioneuvosto.fi/bitstream/ handle/10024/162955/TEM_2021_18.pdf

(30) Eurofound Living, working and COVID-19. COVID-19 series, Publications Office of the European Union, Luxembourg. Luettu 15.5.2021. https://www.eurofound.europa. $\mathrm{eu} /$ sites/default/files/ef_publication/field_ef_ document/ef20059en.pdf

(31) Bentley TA, Teo STT, McLeod L, ym. The role of organizational support in teleworker wellbeing: A Socio-technical systems approach. Appl Ergon 2016;52:207-215 doi: 10.1016/J.APERGO.2015.07.019

(32) Laukka E, Gluschkoff K, Kaihlanen A-M, ym. Muutos psykiatrisen avoihoitokäyntien toteutuksessa ja johtajien kokemukset etäasiointia estävistä ja edistävistä tekijöistä COVID-19-aikakaudella. FinJeHeW 2021;13(1):49-62 doi: 10.23996/fjhw.98228

(33) Heponiemi T, Hyppönen H, Vehko T, ym., Finnish physicians' stress related to information systems keeps increasing: A longitudinal three wave survey study. BMC Med Inform Decis Mak 2017;17:147. doi: https://doi.org/10.1186/s12911-017-0545-y 
(34) Heponiemi T, Kujala S, Vainiomäki S, ym. Usability Factors Associated With Physicians' Distress and Information System-Related Stress: Cross-Sectional Survey. JMIR Med Inform 2019; 7(4):e13466. doi: 10.2196/13466

(35) Heponiemi T, Vänskä J, Aalto A-M, ym. Kyselyt lääkäreille 2006 ja 2010: Potilastyöhön ja tietojärjestelmiin liittyvä stressi lisääntyi. Lääkärilehti 2012;47:3491-3495

(36) Ristolainen M, Maijala R, Eloranta S. Viestintä osana etäjohtamista terveydenhuollossa. FinJeHew 2020;12(3):179-186. doi: https://doi.org/10.23996/fjhw.95051

(37) Cowan L. e-Leadership: Leading in a Virtual Environment - Guiding Principles For Nurse Leaders. Nurs Econ 2014;32(6):312-322.

(38) Sharpp T J, Lovelace K, Cowan L D \& Baker D. (2019) Perspectives of nurse managers on information communication technology and e-Leadership. J Nurs Manag 2019;27:15541562. doi: 10.1111/jonm.12845

(39) Holland B, Malve D, Fottler M. Health Care Globalization. A Need for Virtual Leadership. The Health Care Manager 2009; 28(2):117-123. doi: 10.1097/HCM.0b013e3181a2cb63

(40) Collins S, Yen P-Y, Phillips A, ym. Nursing Informatics Competency Assessment for the Nurse Leader J Nurs Adm 2017;47(4):212218. doi: https://doi.org/10.1097/ NNA.0000000000000467.

(41) Lincoln YS, Guba EG. Naturalistic inquiry. Newbury Park: SAGE Publications; 1985
ANNIKa RaVELIN

$T t M^{1}$, vieraileva tutkija ${ }^{2}$

${ }^{1}$ Hoitotieteen ja terveyshallintotieteen tutkimusyksikkö, Oulun yliopisto, Oulu, Suomi ${ }^{2}$ Hyvinvointivaltion tutkimus ja undistaminen yksikkö, Terveyden ja hyvinvoinnin laitos, Helsinki, Suomi

\section{ELINA LAUKKA}

sh, TtM, yliopisto-opettaja ${ }^{1}$, vieraileva tutkija ${ }^{2}$

${ }^{1}$ Hoitotieteen ia terveyshallintotieteen tutkimusyksikkö, Oulun yliopisto, Oulu, Suomi ${ }^{2}$ Hyvinvointivaltion tutkimus ja undistaminen yksikkö, Terveyden ja hyvinvoinnin laitos, Helsinki, Suomi

\section{Tarja Heponiemi}

PsT, tutkimusprofessori

Hyvinvointivaltion tutkimus ja undistaminen yksikkö, Terveyden ja hyvinvoinnin laitos, Helsinki, Suomi

\section{Anu Kaihlanen}

TtT, erikoistutkija

Hyvinvointivaltion tutkimus ja undistaminen yksikkö, Terveyden ja hyvinvoinnin laitos, Helsinki, Suomi

\section{OUti Kanste}

sh, TtT, yliopistonlehtori

Hoitotieteen ja terveyshallintotieteen tutkimusyksikkö, Oulun yliopisto, Oulu, Suomi 